\title{
A Human T Cell Lymphoma Secreting an Immunoglobulin E Specific Helper Factor
}

Michael C. Young, Harb Harfi, Rajih Sabbah, Donald Y. M. Leung, and Raif S. Geha

Division of Allergy, The Children's Hospital and Department of Pediatrics, Harvard Medical School, Boston, Massachusetts 02115; and Departments of Pediatrics, Oncology, and Pathology, The King Faisal Specialist Hospital and Research Center, Riyadh, Saudi Arabia

\begin{abstract}
An 8-yr-old nonallergic girl with non-Hodgkin's lymphoma had markedly elevated serum IgE at presentation $(>10,000$ IU/ml), negative skin tests to a battery of 24 common allergens, and no evidence of parasitic infestation. Serum levels of IgG, IgA, and IgM were normal. Remission after cytotoxic chemotherapy was accompanied by a marked reduction in serum IgE levels (to $<200 \mathrm{IU} / \mathrm{ml}$ ) with no change in the level of serum IgG, IgM, or IgA. Recurrence of the lymphoma 7 mo after remission was accompanied by an isotype specific rise in serum IgE (to $3,850 \mathrm{IU} / \mathrm{ml}$ ). Isoelectric focusing revealed that the IgE was polyclonal.

Phenotypic analysis of the lymphoma obtained during relapse revealed all $(>98 \%)$ cells to be $\mathrm{T} 3+, \mathrm{T} 4+$, and $\mathrm{T8}+$. Incubation of lymphoma cells with human myeloma IgE followed by immunosorbent purified fluorescein tagged goat anti-human IgE (anti-IgE PS-adsorbed over IgE ADZ) stained 25\% of the cells. In contrast, $<1 \%$ of the cells were stained after incubation with human IgG followed by fluorescein conjugated goat antihuman IgE. Supernatants from lymphoma cells $\left(5 \times 10^{6} / \mathrm{ml}\right.$, 48 h) enhanced IgE production in B cells derived from four patients with allergic rhinitis (mean \pm SD picograms per milliliter of net IgE $930 \pm 320$ in unstimulated cultures versus $2,450 \pm 650$ in cultures stimulated with lymphoma supernatants; $P<0.01$ ) but did not induce IgE synthesis in $B$ cells from two normal subjects that synthesized no IgE spontaneously. Lymphoma supernatants failed to enhance IgG synthesis by $B$ cells of both allergic and nonallergic subjects.

These results indicate that a $\mathbf{T}$ cell lymphoma comprised of cells bearing Fc receptors for IgE with a phenotype characteristic of immature $\mathbf{T}$ cells (i.e., $\mathrm{T} 3+, \mathrm{T} 4+, \mathrm{T} 8+$ ) exhibited IgE specific helper function. This lymphoma may represent the monoclonal expansion of a subpopulation of IgE specific helper $\mathbf{T}$ cells.
\end{abstract}

\section{Introduction}

Substantial evidence in experimental animals indicates that IgE synthesis is under the control of regulatory $T$ cells $(1,2)$.

Portions of this work were presented at the 76th annual meeting of the American Society for Clinical Investigation, Washington, DC, May 4-7, 1984.

Dr. Young received National Research Service Award 1 F32 A106717.01. Dr. Leung received New Investigator Award 5R23HL30082-02. Dr. Geha received Allergic Diseases Academic Award K07 AI0440-01. Address correspondence to Dr. Geha, The Children's Hospital, Division of Allergy, 300 Longwood Ave., Boston, MA 02115 .

Received for publication 30 November 1984 and in revised form 19 February 1985

J. Clin. Invest.

(c) The American Society for Clinical Investigation, Inc. 0021-9738/85/06/1977/06 \$1.00

Volume 75, June 1985, 1977-1982
IgE specific helper $T$ cells have been described in the rat by Ishizaka and co-workers $(3,4)$. They appear to bear Fc receptors for $\operatorname{IgE}\left(\mathrm{Fc}_{\boldsymbol{e}} \mathrm{R}\right)^{1}$ and to secrete glycoproteins that bind to IgE, i.e., IgE binding factors. Functional studies indicate that highly glycosylated IgE binding factors potentiate IgE synthesis in an isotype specific manner. We have recently derived $F c_{\epsilon} R$ positive $T$ cell lines from the blood of patients with the hyper-IgE syndrome and we have shown that these lines secrete into their supernatants a factor(s) that provides IgE specific help (5). This factor binds to IgE, is glycoprotein in nature, and acts on IgE bearing B cells.

In this study we describe a patient with a non-Hodgkin's lymphoma and extremely elevated serum IgE. The serum IgE in this patient returned to the normal range with the regression of the tumor only to rise again when the tumor recurred. Cell surface analysis of the tumor cells revealed them to be $\mathrm{T} 3+$, $\mathrm{T} 4+$, and $\mathrm{T} 8+$ and to bear $\mathrm{Fc}_{\mathrm{\epsilon}} \mathrm{R}$. The tumor cells released into their culture supernatants an IgE specific enhancing factor that had affinity for IgE. The patient's tumor may represent a malignant proliferation of a subpopulation of IgE specific helper $\mathrm{T}$ cells.

Case report. An 8-yr-old female was admitted to the King Faisal Hospital, Riyadh, Saudi Arabia, with a 3-mo history of chest pain, cough, and shortness of breath. Physical examination revealed a thin child, $28 \mathrm{~kg}$ in weight, $129 \mathrm{~cm}$ in height, with a bulging left hemithorax, absent breath sounds over the left chest field, and decreased breath sounds over the right chest field. Cervical, axillary, and left inguinal lymph nodes were moderately enlarged. The liver and spleen edges were each 5 cm below the costal margin. Chest $\mathrm{x}$-ray revealed a completely opaque left hemithorax and a mediastinal shift to the right. Computerized axial tomography scan revealed a solid tumor filling the left hemithorax. Pleural fluid from the left chest revealed no malignant cells but abundant eosinophils and few lymphocytes. Histologic examination of the chest mass biopsy revealed cells with irregular nuclei, most of which were convoluted; scanty cytoplasm, and undifferentiated and inconspicuous nucleoli. There were occasional plasma cells and a small number of eosinophils. Fig. 1 shows an electron micrograph of the tumor, which illustrates the irregular convoluted nuclei observed in the majority of the tumor cells and a high nuclear to cytoplasmic ratio. There was a lack of intercellular junctions, of neurosecretory granules, and of cytoplasmic filaments.

On admission, the leukocyte count was $11,400 \mathrm{cells} / \mathrm{mm}^{3}$ with $67 \%$ eosinophils, $31 \%$ neutrophils, $7 \%$ lymphocytes, and $5 \%$ monocytes. Bone marrow aspiration revealed a hypercellular marrow with increased eosinophil precursors. No malignant cells were observed in peripheral blood or bone marrow smears. Because of the blood and bone marrow eosinophilia, a serum IgE level was taken and was $>10,000 \mathrm{IU} / \mathrm{ml}$. This

1. Abbreviations used in this paper: $\mathrm{E}$, erythrocytes; $\mathrm{Fc}_{\mathrm{e}} \mathrm{R}, \mathrm{Fc}$ receptors for IgE; $F c_{e} R+, F c_{e} R$ positive; FCS, fetal calf serum; HS, horse serum; PBMC, peripheral blood mononuclear cells. 


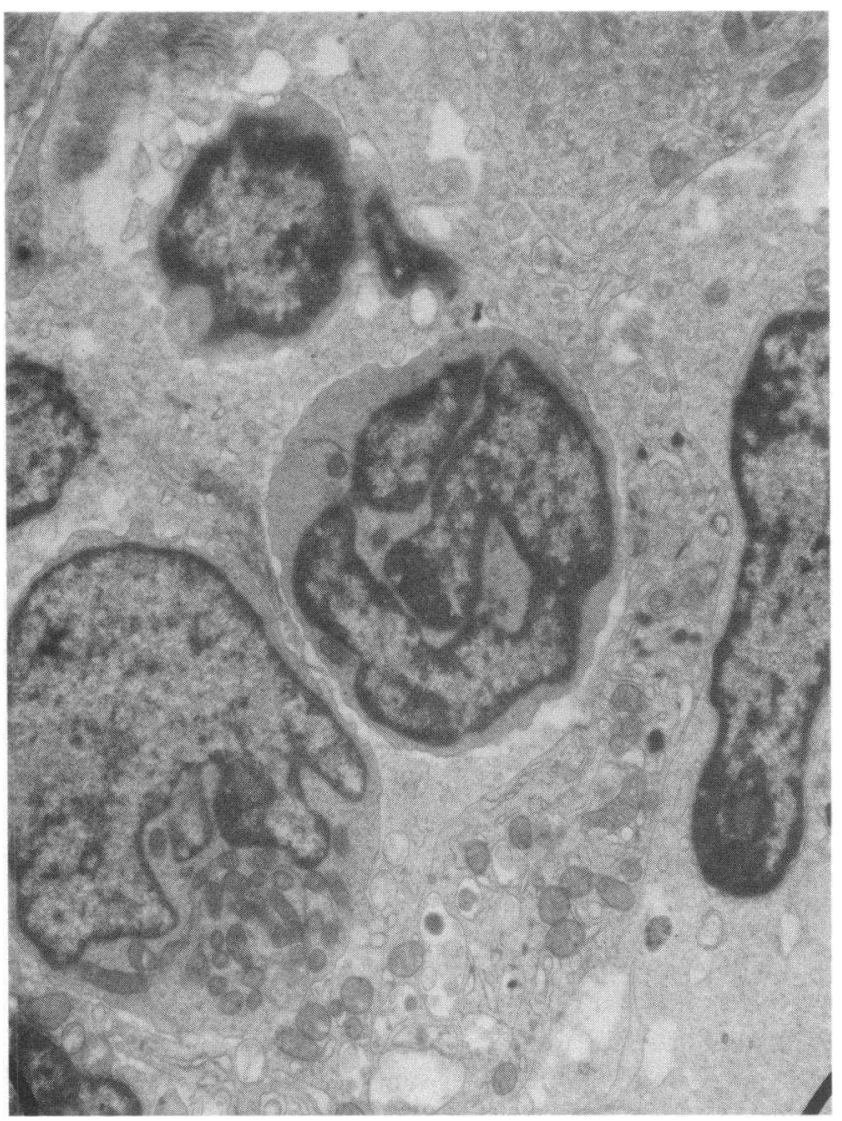

Figure 1. Electron micrograph of the tumor. Note the convoluted nuclei, the lack of nucleoli, and the large nuclear to cytoplasmic ratio.

was confirmed by a repeat determination. There was no personal or family history of allergic disease. A battery of 24 hypersensitivity skin tests for inhalant allergens was negative as were repeated stool examinations $(\times 5)$ for ova and parasites. Analysis of the serum IgE by isoelectric focusing was performed by Dr. Z. Audeh (Center for Blood Research, Boston, MA) and revealed a polyclonal pattern. IgG was $1,388 \mathrm{mg} / 100 \mathrm{ml}$ (normal, 568-1,483 mg/100 ml), IgA was 123 (normal, 57$414 \mathrm{mg} / 100 \mathrm{ml}$ ), and IgM was $84 \mathrm{mg} / 100 \mathrm{ml}$ (normal, 120 $274 \mathrm{mg} / 100 \mathrm{ml}$ ). An SMA 20 analysis was normal except for an elevated lactate dehydrogenase $(1,128 \mathrm{U}$ vs. a normal of $100-225 \mathrm{U} / \mathrm{ml}$ ) and a low albumin of $2.5 \mathrm{~g} / 100 \mathrm{~m}$.

Fig. 2 summarizes the changes in serum IgE levels and total eosinophil counts during the course of the therapy. $8 \mathrm{wk}$ after the initiation of treatment (Feb. 1983), there was no clinical or radiologic evidence of tumor. Serum IgE at that time was $767 \mathrm{IU} / \mathrm{ml}$. Serum IgM, IgG, and IgA remained essentially unchanged ( $<10 \%$ change). 5 mo later (May 1983), there was still no evidence of disease and the patient's serum IgE at that time was $200 \mathrm{IU} / \mathrm{ml}$. Serum IgM, IgG, and IgA were unchanged. $7 \mathrm{wk}$ later a mild enlargement of the left side of the mediastinum was observed on chest radiography. Subsequently, over a 3-mo period, a left medistinal mass became clearly visible and grew larger despite the continued administration of cytotoxic drugs. This was accompanied by a rise in serum IgE (up to $3,900 \mathrm{IU} / \mathrm{ml}$ ). At that time a course of ara$\mathrm{C}(300 \mathrm{mg} \times 3 \mathrm{~d})$ and of VP16 (250 mg for $2 \mathrm{~d})$ was administered. This was quickly followed by a drop in serum IgE,

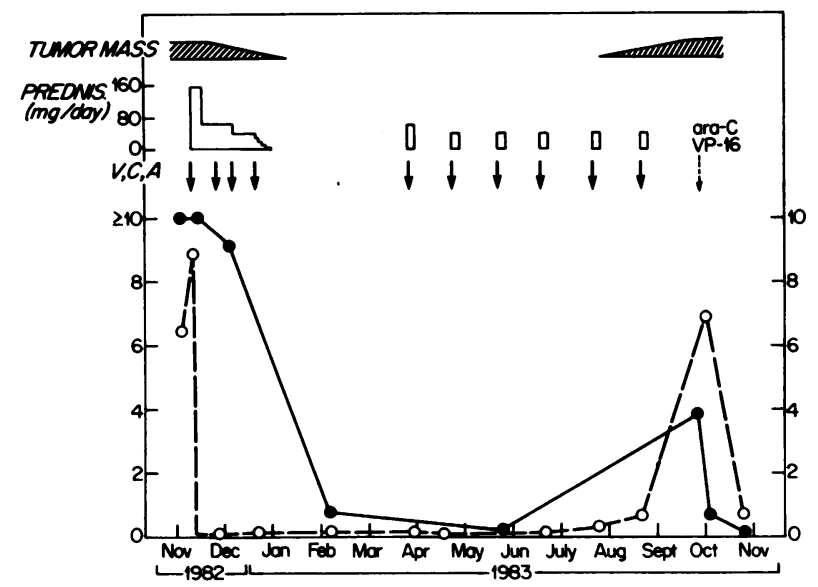

Figure 2. Schematic representation of the clinical course of the patient. (-๑-), IgE (IU/ml) $\times 10^{-3}$; (---০---), eosinophils, $\mathrm{mm}^{3}$ $\times 10^{-3}$. The tumor mass was estimated from the chest radiograph. Courses of Vincristine (V), Cyclophosphamide (C), and Adriamycin (A), and of ara-C and V-P 16 are indicated by arrows. PREDNIS, prednisone.

from $3,900 \mathrm{IU} / \mathrm{ml}$ to $746 \mathrm{IU} / \mathrm{ml}$ in a period of $8 \mathrm{~d}$. In contrast, serum IgG, IgM, and IgA remained in the normal range.

Examination of Fig. 2 shows the peripheral blood eosinophilia present initially rapidly resolved with the administration of prednisone. However, the blood eosinophil count rose rapidly with the recurrence of the tumor mass. Although at that time the neutrophil count rose by 2.5 -fold, the eosinophil count concomitantly rose from $100 / \mathrm{mm}^{3}$ to $6,800 / \mathrm{mm}^{3}$.

\section{Methods}

Isolation of tumor cells. Tumor tissue was teased with fine scissors in medium RPMI 1640 containing 10\% fetal calf serum (FCS). Debris was allowed to settle and the suspension was filtered through a short column of glass wool. These cells were incubated for two cycles, $1 \mathrm{~h}$ each, at $37^{\circ} \mathrm{C}$ in Petri dishes. Nonadherent cells were collected, washed three times, and suspended at $5 \times 10^{6}$ cells $/ \mathrm{ml}$ in RPMI- $10 \%$ FCS.

Tumor cell lines. The human tumor T cell line CEM-6 was a gift of Dr. A. Fauci (National Institutes of Health, Bethesda, MD). The tumor cell line RPMI 8866 was a gift of Dr. K. Ishizaka (Johns Hopkins, Baltimore, MD). This human lymphoblastoid B cell line expresses receptors for human IgE.

Isolation of peripheral blood mononuclear cells (PBMC). PBMC were isolated from heparinized peripheral blood by Ficoll-Hypaque (Pharmacia Fine Chemicals, Piscataway, NJ) density gradient centrifugation. The isolated PBMC were washed three times in Hank's balanced salt solution and suspended in RPMI 1640 medium containing $10 \%$ FCS

Isolation of $B$ cells. Suspensions of PBMC were depleted of adherent cells by allowing them to incubate for $1 \mathrm{~h}$ at $37^{\circ} \mathrm{C}$ in plastic Petri dishes $\left(5 \times 10^{6}\right.$ cells $\left./ \mathrm{ml}\right)$. Cell suspensions enriched in B cells were prepared by rosetting nonadherent mononuclear cells with sheep erythrocytes (E) pretreated with neuraminidase and recovering the nonrosette-forming cells by centrifugation over Ficoll-Hypaque (6). After repeating the rosetting procedure a second time, the nonrosetteforming cells contained $70-85 \%$ surface $\mathrm{Ig}^{+}$cells, and $<2 \% \mathrm{E}+$ cells.

Analysis of surface markers. T cell surface markers of the tumor cells were analyzed by indirect immunofluorescence using the monoclonal antibodies OKT3, OKT4, and OKT8 (Ortho Diagnostic Systems, Inc., Raritan, $\mathrm{NJ}$ ), control mouse ascites, and fluorescein conjugated $\mathrm{F}\left(\mathrm{ab}^{\prime}\right)_{2}$ goat anti-mouse Ig (Tago Inc., Burlingame, CA) as described previously (7). The percent of cells bearing surface Igs was determined 
by direct immunofluorescence using fluorescein conjugated polyvalent goat anti-human Igs (Cappel Laboratories, Cochranville, PA). Background staining was always $<2 \%$ and was subtracted from the experimental values.

Fluorescence was read under a fluorescent microscope (Carl Zeiss, Inc., Thornwood, NY) with epi-illumination by two individuals who had no knowledge of the contents of the samples. The average of the two readings was taken. The two readings were always in close agreement with each other.

Analysis of Fc receptors for IgE. Tumor cells were incubated at 5 $\times 10^{6} / \mathrm{ml}$ in RPMI $164010 \%$ FCS and $0.1 \%$ sodium azide with a solution of $10 \mu \mathrm{g} / \mathrm{ml}$ of human myeloma IgE or with a solution of 10 $\mu \mathrm{g} / \mathrm{ml}$ of human IgG. This IgG was a Cohn's Fraction II (Massachusetts Biologicals, Jamaica Plain, MA) purified further over DEAE. After incubation for $45 \mathrm{~min}$ on ice, the cells were washed three times in the above medium. The cells were resuspended to the original volume and incubated with a 1:10 dilution of a 10-25 $\mu \mathrm{g} / \mathrm{ml}$ of fluorescein conjugated goat anti-human IgE. This antiserum was obtained by immunizing a goat with human IgE, isolating the IgG fraction of the antiserum, and absorbing it with human IgM, IgG, IgA, myelomas, and $\mathrm{K}$ and $\mathrm{L}$ Bence Jones proteins followed by immunosorbent purification over a column of IgE myeloma. The goat anti-human IgE was then fluorescein conjugated according to the procedure described in (8). After $45 \mathrm{~min}$ at $4^{\circ} \mathrm{C}$ the cells were washed three times and fluorescence was determined as described above. Background fluorescence of cells preincubated with IgG was $<2 \%$ and was subtracted from the experimental value.

Assay for the secretion of helper factors by tumor cells. Cells were incubated at $5 \times 10^{6}$ cells/ml in RPMI $1640-10 \%$ FCS for $48 \mathrm{~h}$ at $37^{\circ} \mathrm{C}$. Culture supernatants were collected and then passed through a CF50-A Centriflo membrane (Amicon Corp., Danvers, MA) with a molecular weight cutoff of $50,000 \mathrm{D}$. The filtrate was sterilized by passage through a $0.45-\mu \mathrm{m}$ millipore filter and was frozen at $-20^{\circ} \mathrm{C}$ until tested.

Induction of IgE synthesis in B cells. Tumor cell supernatants were assessed for their capacity to enhance IgE synthesis by cultures of B cells obtained from four subjects with allergic rhinitis whose serum IgE levels ranged from 200 to $400 \mathrm{IU} / \mathrm{ml}$, respectively, and on B cells from two normal subjects (serum IgE of $<10 \mathrm{IU} / \mathrm{ml}$ ).

The $\mathrm{E}$ rosette-negative cells were washed and resuspended in RPMI 1640 with $10 \%$ FCS at a concentration of $1.0 \times 10^{6}$ cells $/ \mathrm{ml}$ The cells were placed in $0.5-1 \mathrm{ml}$ volumes $(12 \times 75-\mathrm{mm}$ plastic tubes $)$ in the presence or absence of tumor cell supernatants used at a final concentration of $10 \%$. After $7 \mathrm{~d}$ the supernatants were collected, and their IgE and IgG contents were determined. All cultures were made in duplicate. In vivo preformed cytophilic IgE was determined by acid elution of B cells on day 0 as described by Turner et al. (9). After $7 d$ of culture, supernatants were collected and their IgE and IgG contents were determined. Net IgE synthesis was calculated by subtracting the values for IgE obtained in day $\mathbf{0}$ acid eluted cell pellets, i.e., preformed IgG from IgE values of day 7 supernatants.

Radioimmunoassay (RIA) for IgE. Duplicate samples from each culture were analyzed for their IgE content. The RIA for IgE was performed in flexible flat-bottom microtiter plates (Cooke Laboratory Products, Alexandria, VA). The wells were filled with $0.1 \mathrm{ml}$ of a 10 $\mu \mathrm{g} / \mathrm{ml}$ solution of a $1: 1$ mixture of two monoclonal antihuman IgE Fc-specific antibodies. These two antibodies $(8,9)$ were a kind gift of Dr. Siraganian (National Institutes of Health, Bethesda, MD). After incubation for $16 \mathrm{~h}$, the coating solution was removed, and the wells were washed and blocked with $10 \%$ horse serum (HS) in phosphatebuffered saline (PBS) for $2 \mathrm{~h}$. After washing three times with PBS containing $1 \% \mathrm{HS}, 0.1 \mathrm{ml}$ of culture supernatant or of IgE standard was added to each of the triplicate wells and incubated for $16 \mathrm{~h}$ in a humidified chamber at room temperature. The wells were then washed two times with PBS $1 \%$ HS containing $0.5 \%$ Tween 20 and twice with PBS $1 \% \mathrm{HS}$; then $0.1 \mathrm{ml}$ of Phadebas radioallergo-sorbent test ${ }^{125} \mathrm{I}-$ anti-human IgE (Pharmacia Fine Chemicals; sp act $12 \mu \mathrm{Ci} / \mu \mathrm{g}$ ) was added to each well. $6 \mathrm{~h}$ later the radiolabeled anti-IgE was removed and then wells were washed three times with PBS $1 \%$ HS and eight times under running distilled water. The wells were cut out and counted in a Gamma spectrometer (Tracor Analytic, Elk Grove Village, IL). Standard curves were constructed using dilutions of the IgE standards obtained from Pharmacia Fine Chemicals. The concentration of IgE in the supernatants was read from the standard curve. The lower limit of sensitivity of this assay varied from 150 to $300 \mathrm{pg} / \mathrm{ml}$.

The specificity and sensitivity of our IgE RIA was confirmed in a recently completed multi-institutional study coordinated by the Mayo Clinic (Yunginger, J. W., R. M. Helm, and G. J. Gleich; manuscript in preparation). Coded samples with varying quantities of polyclonal IgE in the presence of other Ig isotypes sent to our laboratory were evaluated using our IgE RIA. In no test sample were falsely elevated IgE values measured; this ruled out the possibility of cross-reactivity with other isotypes. Furthermore, values of $\mathrm{IgE}>300 \mathrm{pg} \mathrm{IgE} / \mathrm{ml}$ were measured accurately within $10 \%$ of expected values.

Determination of $\operatorname{IgG}$. IgG in culture supernatants was measured by a solid-phase competitive RIA as previously described (10).

IgE binding capacity of $T$ lymphoma supernatants. To demonstrate the IgE binding capacity of the tumor cell supernatants, the supernatants were circulated over a column of human IgE (PS) conjugated to Sepharose $4 \mathrm{~B}$ overnight at $4^{\circ} \mathrm{C}$. Sepharose beads conjugated to human IgG DEAE purified Cohn fraction II (Massachusetts Biologicals) were used as controls. After collection of the effluent, the beads were washed with PBS, and eluted with $0.2 \mathrm{M}$ glycine- $\mathrm{HCl}$ at $\mathrm{pH} 3.0,4^{\circ} \mathrm{C}$. The eluate was collected into tubes containing an appropriate amount of $0.1 \mathrm{M}$ Tris buffer, $\mathrm{pH} 8.6$, so that the final $\mathrm{pH}$ of the eluate was between 7.0 and 8.0. The final volume of the eluate was made up with PBS to the original volume. The eluates were then immediately dialyzed (Spectropor dialysis membrane with a cutoff of 3,500 D) against RPMI 1640, passed through a CF50A Centriflo membrane, and subsequently sterilized by filtration through a $0.45-\mu \mathrm{m}$ millipore filter and frozen at $-20^{\circ} \mathrm{C}$ until tested.

\section{Results}

Surface phenotype of tumor cells. The surface phenotype of the tumor cell is shown in Table I. Almost all tumor cells expressed the T3, T4, and T8 antigens. There were no detectable B cells as evidenced by lack of surface Ig positive cells. $25 \%$ of the tumor cells expressed Fc receptors for IgE as determined by indirect immunofluorescence. Using the same method, $85 \%$ of the RPMI 8866 cell line was found to be $F_{c} R$ positive $\left(F c_{\epsilon} R+\right)$, whereas no $F c_{\epsilon} R+$ cells could be detected in the CEM-6 cell line. The phenotypic analysis of peripheral blood lymphocytes of the patient was determined simultaneously and was found to be normal.

Enhancement of IgE synthesis by tumor cell supernatants. The effect of the tumor cell supernatants on IgE synthesis was examined by adding the supernatants at a final solution of 1 : 10 to cultures containing B cells obtained from allergic donors or from normal subjects.

Fig. 3 shows that the tumor B cell supernatants selectively enhanced IgE synthesis in the B cells of four allergic subjects studied. The preformed IgE in acid treated cell pellets was equivalent in B cells to which medium or $T$ lymphoma supernatants were added. The mean total IgE present in 7-d cultuies of $B$ cells that received $T$ lymphoma supernatants $(2,450 \pm 650 \mathrm{pg} / \mathrm{ml})$ was significantly higher $(P<0.01)$ than the mean total $\mathrm{IgE}$ present in B cells cultured with medium alone $(930 \pm 320 \mathrm{pg} / \mathrm{ml})$. In contrast, $\mathrm{T}$ lymphoma supernatants did not enhance IgG synthesis in the B cells from the allergic subjects (Fig. 3).

The effect of $T$ lymphoma supernatants was studied on B cells from normal subjects. These cells contained no detectable preformed IgG $(<200 \mathrm{pg} / \mathrm{ml})$ and failed to synthesize any detectable IgE regardless of the presence or absence of added 
Table I. Phenotypic Analysis of the Patient's Lymphoma

\begin{tabular}{|c|c|c|c|c|}
\hline \multirow[b]{2}{*}{ Marker } & \multicolumn{4}{|c|}{ Percent positive cells } \\
\hline & $\begin{array}{l}\text { Patient's } \\
\text { tumor }\end{array}$ & RPMI 8866 & CEM-6 & $\begin{array}{l}\text { Patient's } \\
\text { PBMC }\end{array}$ \\
\hline T3 & 98 & $<1$ & $<1$ & 75 \\
\hline T4 & 98 & $<1$ & 98 & 48 \\
\hline T8 & 98 & $<1$ & 60 & 23 \\
\hline sIg & $<1$ & 96 & $<1$ & 5 \\
\hline Fc IgE & 25 & 85 & $<1$ & $<1$ \\
\hline
\end{tabular}

The surface phenotype of the patient's suspended lymphoma cells, RPMI 8866 cells, CEM-6 cells, and PBMC from the patient was determined by immunofluorescence as described in Methods. All determinations were done on coded samples, the identities of which were withheld from the investigators reading the immunofluorescence.

T cell supernatants. Furthermore, their spontaneous IgG synthesis was not enhanced by $\mathrm{T}$ lymphoma supernatants.

Table II summarizes the data obtained in all experiments. Data are expressed as net IgE and IgG synthesis by subtracting the preformed values of IgE and IgG from the values in 7-d cultures.

It was important to ascertain that the observed increased IgE values in supernatants of cultures stimulated with $T$ lymphoma supernatants represented de novo IgE synthesis. B cells from four separate allergic subjects were cultured in the presence or absence of the protein synthesis inhibitor cycloheximide $(100 \mu \mathrm{g} / \mathrm{ml})$ and the culture supernatants were assayed for IgE and IgG after a 7-d incubation period. The results in Table III clearly show that cycloheximide inhibited the induction of IgE synthesis by $\mathrm{T}$ lymphoma supernatants.

Affinity of IgE enhancing factor for IgE. Supernatants from the tumor cells were examined for their capacity to enhance IgE synthesis in allergic $B$ cells before and after passage of these supernatants over columns of Sepharose cross-linked with human IgE or IgG. Fig. 4 depicts the results of two such experiments. Passage of $\mathrm{T}$ lymphoma supernatants over Se-

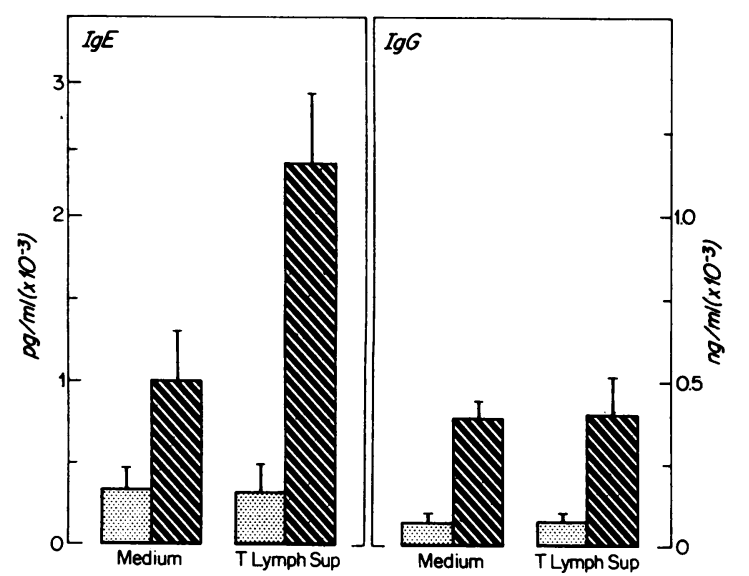

Figure 3. Effect of $\mathrm{T}$ lymphoma supernatants (T Lymph Sup) on IgE and IgG synthesis in cultures of B cells from allergic subjects $(n=4)$. Preformed IgE and IgG were measured by acid treatment of cell pellets ( $(\mathbb{})$ on day 0 . IgE and IgG were measured in supernatants of 7-d cultures of B cells (D). T lymphoma supernatant was added at a final dilution of $1: 10 . P<0.01$. pharose IgE columns depleted their capacity to enhance IgE synthesis. In contrast, passage over Sepharose IgG columns did not affect the capacity of the $T$ lymphoma supernatants to enhance IgE synthesis. Materials that bound to IgE and IgG columns were eluted with glycine $\mathrm{HCl}$ buffer $\mathrm{pH} 3$. This acid eluate was neutralized, dialyzed against RPMI 1640, and passed through a CF50A filter to remove any Ig eluted off the Sepharose and then was tested for IgE enhancing activity in the same B cell cultures. IgE enhancing activity was recovered in acid eluates of IgE Sepharose columns but not of IgG Sepharose columns (Fig. 4).

\section{Discussion}

This study documents the capacity of a human $\mathrm{T}$ cell lymphoma to secrete IgE isotype specific enhancing factor(s). These factor(s), like those secreted by $\mathrm{T}$ cells from parasite infested rats $(3,4)$ and by $T$ cells of patients with the hyper-IgE syndrome (5), had affinity for IgE.

The occurrence of extremely elevated serum IgE levels in a patient with non-Hodgkin's lymphoma who was nonatopic and had no family history of allergic disease brought up the intriguing possibility that these two findings were interrelated. This was strengthened by the observation that during tumor remission induced by cytotoxic drugs, serum IgE levels dropped dramatically, whereas relapse of the lymphoma was associated with a marked rise in serum IgE levels (Fig. 2) but with no changes in serum levels of other isotypes. The increased serum IgE was not due to a monoclonal proliferation of IgE B Cells because isoelectric focusing of serum IgE revealed a polyclonal pattern.

The morphology of the patient's tumor cells, in particular the presence of convoluted nuclei (Fig. 1), was suggestive of T cells. The $T$ cell nature of these cells was confirmed by phenotypic analysis of tumor cells obtained during the relapse. This showed $98 \%$ of cells to be $\mathrm{T} 3+, \mathrm{T} 4+$, and $\mathrm{T} 8+$ (Table I). This phenotype is thought to be characteristic of immature thymocytes (stage III thymocytes), which have not yet differentiated along either the T4 or the T8 pathway, despite acquiring the T3 antigen, which is specific for T cells (11). In this regard, circulating $T$ cells coexpressing the $T 3, T 4, T 8$, and $\mathrm{T} 10$ surface antigens have been reported to occur in some patients with severe combined immunodeficiency syndrome (12). In these patients a block in $T$ cell maturation and differentiation could have resulted in the appearance of immature $T$ cells in the periphery.

Since $T$ cells are known to play an important role in the potentiation of IgE synthesis, we further investigated the functional activity of soluble factors secreted by this patient's lymphoma cells. These studies revealed that her $T$ cell lymphoma produced factors that enhanced IgE synthesis by B cells from patients with allergic rhinitis but not by B cells from normal donors (Table II, Fig. 3). This enhancement was isotype specific because no changes were observed in IgG synthesis by the same B cell cultures after addition of lymphoma supernatants. Characterization of the IgE potentiating factor revealed that it could bind to immobilized IgE but not to immobilized IgG and was, thus, an IgE binding factor (Fig. 4). The observation that this factor exerted biologic activity on B cells from allergic donors, which spontaneously secrete IgE but not on normal $B$ cells that do not synthesize IgE spontaneously, suggests that this factor exerts its effect on IgE $B$ cells that are spontaneously activated in vivo and that 
Table II. Effect of T Lymphoma Supernatants on Net IgE and IgG by B Cells of Allergic and Normal Subjects

\begin{tabular}{|c|c|c|c|c|c|c|}
\hline \multirow[b]{2}{*}{ Source of B cells } & \multicolumn{3}{|c|}{ Net IgE synthesis $(\mathrm{pg} / \mathrm{ml})$} & \multicolumn{3}{|c|}{ Net $\mathrm{IgG}$ synthesis $(\mathrm{ng} / \mathrm{ml})$} \\
\hline & $\begin{array}{l}\text { Culture } \\
\text { medium }\end{array}$ & $\begin{array}{l}\text { T lymphoma } \\
\text { supernatants }\end{array}$ & $\begin{array}{l}\text { Enhancement } \\
(\Delta)\end{array}$ & $\begin{array}{l}\text { Culture } \\
\text { medium }\end{array}$ & $\begin{array}{l}\text { T lymphoma } \\
\text { supernatants }\end{array}$ & $\begin{array}{l}\text { Enhancement } \\
(\Delta)\end{array}$ \\
\hline $\begin{array}{l}\text { Allergic subjects } \\
\qquad(n=4)\end{array}$ & $663 \pm 320$ & $1_{1}^{1,995 \pm 417}$ & 1,332 & $320 \pm 88$ & $346 \pm 110$ & 26 \\
\hline $\begin{array}{l}\text { Normal subjects } \\
\quad(n=2)\end{array}$ & $<200$ & $<200$ & $<200$ & $232 \pm 46$ & $281 \pm 34$ & 49 \\
\hline
\end{tabular}

Mean \pm 1 SD of net IgE and IgG synthesis by B cells from four patients with allergic rhinitis and B cells from two normal subjects cultured in the presence of culture medium or supernatant from the $T$ cell lymphoma cells are shown. Preformed cytophilic IgE was determined by acid elution of cells on day 0 , and net IgE synthesis was calculated by subtracting preformed IgE from IgE secreted into $\mathrm{B}$ cell supernatants after $7 \mathrm{~d}$ of culture. The same formula was used to calculate net IgG synthesis. T lymphoma supernatants but not culture medium enhanced IgE synthesis $(P<0.01)$ but not IgG synthesis by B cells from allergic subjects.

circulate in allergic but not in normal subjects (13). Thus, this factor seems to work as a differentiation factor at a rather late stage in the differentiation of IgE B cells.

Numerous studies carried out in rodents have demonstrated that IgE binding factors secreted by $\mathrm{T}$ cells that bear $\mathrm{Fc}$ receptors for IgE play an important role in modulating $\operatorname{IgE}$ synthesis. In a series of elegant studies using the rat model, Ishizaka and co-workers $(3,14)$ have shown that $T$ cells from animals infected with Nippostrongylus brasiliensis spontaneously release IgE binding factors that potentiate IgE synthesis. Such factors are also released by lymphocytes cultured in the presence of low concentrations of Concanavalin $A$ and $\operatorname{IgE}$ (15), and seem to be highly glycosylated proteins. In a recent study, we reported that $F_{c} R+T$ cell lines derived from patients with the hyper-IgE syndrome released IgE binding factors into their culture supernatants, which potentiated IgE but not IgG synthesis by B cells from patients with allergic rhinitis but not by B cells from normal donors (5).

In view of all these findings, the detection of Fc receptors on $25 \%$ of the lymphoma $\mathrm{T}$ cells was not unexpected (Table I). The observation that only $25 \%$ of lymphoma cells were $\mathrm{Fc}_{\epsilon} \mathrm{R}+$ was also not surprising, as the expression of $\mathrm{Fc}_{\mathrm{\epsilon}} \mathrm{R}$ in $F_{c} R+$ cell lines such as RPMI 8866 is both cell density dependent and cell cycle dependent (unpublished observations).

The $T$ cell phenotype of $\mathrm{Fc}_{\boldsymbol{\epsilon}} \mathrm{R}+\mathrm{T}$ cells in man has only recently been investigated. $<1 \%$ of normal $\mathrm{T}$ cells are $\mathrm{Fc}_{\mathrm{e}} \mathrm{R}+$. Using IgE coated ox erythrocytes in a rosette assay, Spiegelberg et al. (16) have reported that $F_{\epsilon} R+T$ cells are predominantly

Table III. Effect of Cycloheximide on the Induction of IgE Synthesis

\begin{tabular}{llcc}
\hline Culture & $\begin{array}{l}\text { Cyclo- } \\
\text { heximide }\end{array}$ & IgE & IgG \\
\hline & & $p g / m l$ & $n g / m l$ \\
Unstimulated $(n=4)$ & - & $517 \pm 293$ & $230 \pm 120$ \\
& + & $200 \pm 50$ & $42 \pm 33$ \\
& Net & $317 \pm 305$ & $188 \pm 99$ \\
Stimulated with T & - & $1,450 \pm 1,040$ & $217 \pm 133$ \\
lymphoma & + & $200 \pm 71$ & $20 \pm 10$ \\
supernatants $(n=4)$ & Net & $1,250 \pm 992$ & $197 \pm 133$
\end{tabular}

Cycloheximide $(100 \mu \mathrm{g} / \mathrm{ml})$ was added to one set of cultures at the onset of the 7-d incubation period. Cultures of $B$ cells obtained from allergic donors were carried in the presence or absence of a 1:10 dilution of $T$ lymphoma supernatants. of the T8 or M1 phenotype, and are present in mildly allergic subjects but are not present in severely allergic subjects. In contrast, we have found that long-term $F_{\epsilon} R+T$ cell lines derived from patients with hyper-IgE syndrome are predominantly $\mathrm{T} 3+, \mathrm{T} 4+$, i.e., helper phenotype. In this regard, Mitsuya et al. (17) reported a patient with Sezary syndrome and serum IgE of $536,640 \mathrm{IU} / \mathrm{ml}$ whose peripheral $\mathrm{T}$ cells were $98-100 \%$ Leu 3a,b positive (helper/inducer phenotype). These cells provided IgE-specific help in vitro. The failure of Spiegelberg et al. (16) to find increased numbers of $F_{c} R+T$ cells in severely allergic subjects with high serum IgE may relate to the fact that the rosette assay used may not be as sensitive as indirect immunofluorescence in detecting $F c_{\epsilon} R$, and secondly, these investigators did not exclude the possibility that circulating IgE immune complexes in these patients (18, 19) could be blocking $F c_{\epsilon} R$ from rosetting with IgE coated ox erythrocytes.

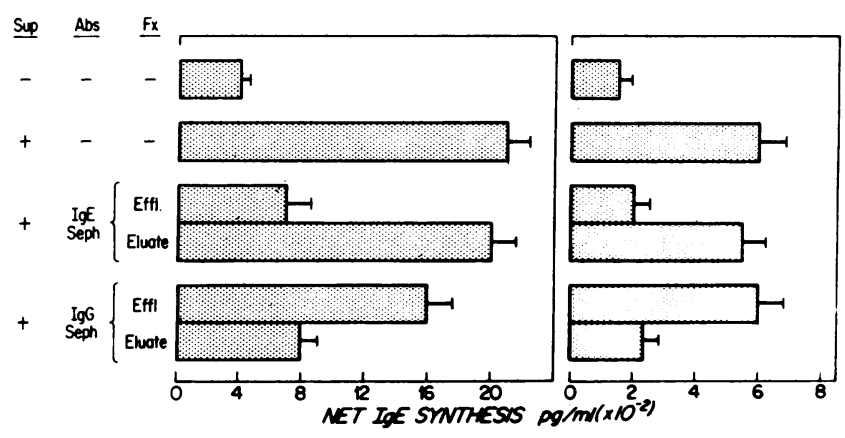

Figure 4. Binding of IgE enhancing activity present in T lymphoma supernatants to human IgE. Lymphoma supernatants (Sup) were filtered through CF50A membranes, then circulated for $18 \mathrm{~h}$ at $4^{\circ} \mathrm{C}$ over Sepharose 4B conjugated with human IgE (IgE Seph) or polyclonal human IgG (IgG Seph). The material that did not bind to the column was designated as effluent (Effl). The columns were then washed extensively with PBS; then the material that bound to the column was eluted with glycine- $\mathrm{HCl}$ pH 3 and dialyzed extensively against RPMI 1640. Both effluent and eluate were passed through a CF50A filter and added in parallel with the unfractionated material at a final concentration of 1:10 to cultures of B cells from allergic subjects. The results show net IgE synthesis. The results of two separate experiments using B cells from two allergic donors are shown. Preformed IgE in experiment no. 1 (left) and experiment no. 2 (right) never exceeded $200 \mathrm{pg} / \mathrm{ml}$. Abs, absorbed against; Fx, fraction. 
If the $\mathrm{T} 3+, \mathrm{T} 4+, \mathrm{T} 8+, \mathrm{Fc}_{\epsilon} \mathrm{R}+$ lymphoma currently studied represents the monoclonal expansion of a normally occurring IgE specific human helper $T$ cell subpopulation, it would suggest that the T4 or T8 surface markers may not be necessarily indicative of IgE helper vs. suppressor function. Recent studies on human $\mathrm{T}$ cell clones have suggested that the T4 and T8 surface antigen play an important role in the recognition of HLA-DR and HLA-A,B histocompatibility antigens rather than imparting helper or suppressor/cytotoxic $T$ cell function (19-22). Further studies are in progress to delineate the heterogeneity of human $T$ cell subpopulations that play a role in regulating IgE synthesis in human.

\section{Acknowledgments}

The authors wish to thank Miss Melissa Smith for excellent secretaria assistance.

The research for this paper was supported by U. S. Public Health Services grants AI-21163 and AI20373; and by grants from the National Foundation and the March of Dimes.

\section{References}

1. Ishizaka, K., and T. Ishizaka, 1978. Mechanisms of reaginic hypersensitivity and IgE antibody response. Immunol. Rev. 41:109148.

2. Katz, D. H. 1980. Recent studies on the regulation of IgE antibody synthesis in experimental animals and man. Immunology. 41:1-24.

3. Yodoi, J., and K. Ishizaka. 1980. Lymphocytes bearing Fc receptors for IgE. IV. Formation of IgE-binding factor by rat $T$ lymphocytes. J. Immunol. 124:1322-1329.

4. Hirashima, M., J. Yodoi, and K. Ishizaka. 1980. Regulatory role of IgE-binding factors from rat $\mathrm{T}$ lymphocytes. III. IgE-specific suppressive factor with IgE-binding activity. J. Immunol. 125:1442-1448.

5. Young, M. C., D. Y. M. Leung, and R. S. Geha. 1984. Production of IgE potentiating factor in man by $\mathrm{T}$ cell lines bearing Fc receptors for IgE. Eur. J. Immunol. 14:871-878.

6. Geha, R. S., F. S. Rosen, and E. Merler. 1973. Identification and characterization of subpopulations and lymphocytes in human peripheral blood after fractionation on discontinuous gradients of albumin. J. Clin. Invest. 52:1726-1734.

7. Leung, D. Y. M., A. R. Rhodes, and R. S. Geha. 1981. Enumeration of $\mathrm{T}$ cell subsets in atopic dermatitis with monoclonal antibodies. J. Allergy Clin. Immunol. 67:450-455.

8. Wood, B. T., S. H. Thompson, and G. Gold. 1965. Fluorescent antibody staining. III. Preparation of fluorescein-isothiocyanate labeled antibodies. J. Immunol. 95:225-229.

9. Turner, K. J., P. G. Holt, B. J. Holt, and K. J. Cameron. 1983.
In vitro synthesis of IgE by human peripheral blood leucocytes. III. Release of preformed antibody. Clin. Exp. Immunol. 51:387-394.

10. Geha, R. S., E. L. Reinherz, D. Leung, K. T. McKee, S. F. Schlossman, and F. S. Rosen. 1981. Deficiency of suppressor T cells in the hyperimmunoglobulinemia E syndrome. J. Clin. Invest. 68:783791.

11. Bhan, A. K., E. L. Reinherz, S. Poppema, R. T. McCluskey, and S. F. Schlossman. 1980. Location of T cell and major histocompatability complex antigens in the human thymus. J. Exp. Med. 152: 771-782.

12. Reinherz, E. L., M. D. Cooper, S. F. Schlossman, and F. S. Rosen. 1981. Abnormalities of $T$ cell maturation and regulation in human beings with immunodeficiency disorders. J. Clin. Invest. 68 : 699-705.

13. Saryan, J. A., D. Y. M. Leung, and R. S. Geha. 1983. Induction of human IgE synthesis by a factor derived from $T$ cells of patients with hyper IgE states. J. Immunol. 130:242-247.

14. Ishizaka, K. 1983. Regulation of IgE response by IgE binding factors. Monogr. Allergy. 18:52-80.

15. Yodoi, J., M. Hirashima, and K. Ishizaka. 1981. Lymphocytes bearing Fc receptors for IgE. V. Effect of tunicamycin on the formation of IgE-potentiating factor and IgE-suppressive factor by Con A-activated lymphocytes. J. Immunol. 126:877-882.

16. Thompson, L. F., M. H. Mellon, R. S. Zeiger, and H. L. Spiegelberg. Characterization with monoclonal antibodies of $\mathrm{T}$ lymphocytes bearing $F c$ receptors for $\operatorname{IgE}\left(\mathrm{T}_{c}\right.$ cells) and $\operatorname{IgG}\left(\mathrm{T}_{\gamma}\right.$ cells) in atopic patients. J. Immunol. 131:2772-2776.

17. Mitsuya, H., M. Sata, T. Hirano, K. Fujimoto, F. Kawano, and S. Kishimoto. 1983. Evidence for a malignant proliferation of IgEclass specific helper $T$ cells in a patient with Sezary syndrome exhibiting massive hyperimmunoglobulinemia E. Clin. Immunol. Immunopathol. 26:171-183.

18. Inganas, M., S. G. O. Johansson, and H. Bennich. 1981. AntiIgE antibodies in human serum: occurrence and specificity. Int. Arch. Allergy Appl. Immunol. 65:51.

19. Quinti, I., C. Brozek, R. S. Geha, and D. Y. M. Leung. 1984. Circulating IgG antibodies to IgE in atopic syndromes. Clin. Res. 32: 146.

20. Krensky, A. M., C. S. Reiss, J. W. Mier, J. L. Strominger, and S. J. Burakoff. 1982. Long-term human cytolytic T-cell lines allospecific for HLA-DR6 antigen are OKT4+. Proc. Natl. Acad. Sci. USA. 79: 2365-2369.

21. Ball, E. J., and P. Stastny. 1982. Cell-mediated cytotoxicity against HLA-DR region products expressed in monocytes and B lymphocytes. IV. Characterization of effector cells using monoclonal antibodies against human $T$ cell subsets. Immunogenetics. 16:159.

22. Meuer, S. C., R. E. Hussey, J. C. Hodgdon, T. Hercend, S. F. Schlossman, and E. L. Reinherz. 1982. Surface structures involved in target recognition of human cytotoxic T lymphocytes. Science (Wash. DC). $218: 471$. 